\title{
The Mechanisms Underlying PTEN Loss in Human Tumors Suggest Potential Therapeutic Opportunities
}

\author{
Hyeyoun Chang ${ }^{1,2,3}$, Zhenying Cai ${ }^{1,2}$ and Thomas M. Roberts ${ }^{1,2, *}$ \\ 1 Department of Cancer Biology, Dana-Farber Cancer Institute, Boston, MA 02215, USA; \\ Hyeyoun_Chang@dfci.harvard.edu (H.C.); Zhenying_Cai@dfci.harvard.edu (Z.C.) \\ 2 Department of Biological Chemistry and Molecular Pharmacology, Harvard Medical School, \\ Boston, MA 02215, USA \\ 3 KIST-DFCI On-Site Lab, Department of Cancer Biology, Dana-Farber Cancer Institute, Boston, MA 02215, USA \\ * Correspondence: Thomas_Roberts@dfci.harvard.edu; Tel.: +1-617-632-3049
}

Received: 28 September 2019; Accepted: 4 November 2019; Published: 7 November 2019

\begin{abstract}
In this review, we will first briefly describe the diverse molecular mechanisms associated with PTEN loss of function in cancer. We will then proceed to discuss the molecular mechanisms linking PTEN loss to PI3K activation and demonstrate how these mechanisms suggest possible therapeutic approaches for patients with PTEN-null tumors.
\end{abstract}

Keywords: PI3K; PTEN; cancer

The phosphoinositide 3-kinase (PI3K) signaling pathway regulates a wide range of vital cellular functions, including cell cycle progression, survival, motility, and metabolism [1]. Because of its central role in integrating multiple extracellular stimuli and intracellular processes, it is not surprising that PI3K signaling is one of the most frequently activated pathways in human cancers [2]. PI3Ks are lipid kinases that phosphorylate the 3'-hydroxyl group of phosphoinositides. The PI3K family is categorized into classes I, II, and III based on structure and substrate specificity. Thus far, only class I PI3Ks have been shown to be directly linked to tumorigenesis and cancer development. Class I PI3Ks are heterodimers composed of a p110 catalytic subunit (p110 $\alpha, \mathrm{p} 110 \beta, \mathrm{p} 110 \gamma$, or $\mathrm{p} 110 \delta)$ and a regulatory subunit ( $\mathrm{p} 85$ or $\mathrm{p} 101$ ), and can be directly activated by cell surface receptors. They are further divided into subclasses IA and IB based on the specific regulatory subunit that couple them to receptors. Both $\mathrm{p} 110 \alpha$ and $110 \beta$ are commonly expressed in cells outside the immune system and are often activated in solid tumors, while p110 and p110 $\gamma$ are expressed in cells of the immune system and are often activated in hematological malignancies [3-5]. The main negative regulator of this pathway is phosphatase and tensin homolog (PTEN) [6-8]. PTEN dephosphorylates phosphatidylinositol (3,4,5)-triphosphate $\left(\mathrm{PIP}_{3}\right)$, a lipid second messenger produced following PI3K activation, to phosphatidylinositol $(4,5)$-bisphosphate $\left(\mathrm{PIP}_{2}\right)$, thereby antagonizing the PI3K signaling pathway. PTEN also functions as a protein phosphatase in the cytoplasm, where it has been shown to inhibit cell migration and induce cell cycle arrest $[9,10]$, or in a phosphatase-independent manner in the nucleus to regulate chromosome stability, DNA repair, and apoptosis [11-14]. Analogously to direct oncogenic activation of PI3K proteins or upstream activators, loss-of-function mutations or epigenetic silencing of the PTEN tumor suppressor has been shown to drive the development of a variety of human cancers [15].

\section{PI3K Mutations in Human Cancers}

Hyperactivation of the PI3K pathway is frequently found in many types of human cancer. Increased activity of the PI3K pathway is often associated with tumor progression and resistance to cancer therapies [16]. Enzymatic activation of the PI3K pathway occurs most frequently through activating mutations in PIK3CA, the gene encoding $\mathrm{p} 110 \alpha$, or through gain-of-function 
mutations/amplification in receptor tyrosine kinases (RTKs) and oncogenes such as KRAS. Preclinical studies have shed light on the reasons that PIK3CA, but not PIK3CB, the gene encoding p110 $\beta$, is so frequently mutated in human tumors. In genetically-engineered mouse (GEM) models, the activation of $\mathrm{p} 110 \alpha$, either directly via activating mutations at so-called hotspots due to their high mutational frequency (E545K and H1047R), or indirectly via activating mutations or overexpression of RTKs, such as Her2, is sufficient to drive tumor formation. In the case of tumors driven by activated RTKs, the deletion of $\mathrm{p} 110 \alpha$ is sufficient to block tumor initiation, while deleting p110 $\beta$ can actually increase tumor size [17]. This appears to occur in part because both enzymes compete for activation motifs on the RTKs, and $\mathrm{p} 110 \alpha$ has a much higher specific activity than p110 $\beta$. This high specific activity may also explain why the PIK3CA gene is a better mutational target in human tumors, though other mechanisms may be relevant. However, the quantitation of class IA PI3Ks using quantitative mass spectrometry revealed at least five times higher loading of p $110 \alpha$-heterodimers than p110 $\beta$-heterodimers to activated platelet-derived growth factor receptors in mouse embryonic fibroblasts [18]. The other major source of PI3K pathway activation in tumors is the loss of the tumor suppressor PTEN. Notably, as will be discussed in more detail below, the activity of p110 $\beta$, the weaker of the two enzymes in terms of catalytic activity, is often essential in PTEN-deficient tumors [19,20].

An integrative analysis of cancer genomics using cBioPortal reported that PIK3CA, PTEN, and/or AKT1 mutations are present in over $40 \%$ of uterine, lung, breast, prostate, brain, and head and neck cancers [21,22]. A targeted, massively parallel sequencing project that assessed the frequency of mutations in 47 genes, including PIK3CA, PTEN, and AKT1, in 19,784 consecutive diverse solid tumors from 60 countries supported previous studies that aberrations in the PI3K pathway are frequently observed in a broad range of human tumors [23]. In addition to uterine, breast, prostate, and lung cancers, the study found that anal, liver, and colorectal cancers also contained mutations in PI3K pathway genes with high frequency.

\section{Prevalence of PTEN Mutations in Cancer}

As one of the most frequently mutated tumor suppressor genes in human cancer, PTEN is altered in a wide range of human cancers, including breast cancer, prostate cancer, endometrial cancer, and glioblastoma [24,25]. PTEN was first discovered as a frequently mutated tumor suppressor gene on chromosome 10q23 [6,8]. Mutation rates in at least one allele of this locus are estimated to occur in the range of $50 \%-80 \%$ in multiple sporadic tumors, including endometrial carcinoma, glioblastoma, and prostate cancer, and at 30\%-50\% in breast, colon, and lung tumors [26]. A cancer genomics study revealed that the tumor suppressor locus in the human genome with the greatest selection for homozygous deletion is PTEN [27]. Somatic mutations on PTEN are scattered along the entire gene. There are mutational hotspots (R130, R173, R233, K267, and N323), but mutations at these hotspots have not been shown to be specific for a certain type of cancer [28]. R130 and $\mathrm{R} 173$, as well as the majority of the missense mutations found in human tumors, are located in the phosphatase domain, affecting the phosphatase activity of PTEN [29]. R233, K267, and N323 are found in the C2 domain, which is essential for lipid binding, thus reducing the ability of PTEN to associate with the plasma membrane [30]. Partial loss of PTEN function is frequently observed in the clinic. Hemizygous loss of PTEN leads to cancer progression in the prostate, thyroid, colon, lymphatic system, mammary gland, and endometrium [31,32]. Studies in mice have shown that even a small decrease in PTEN expression is sufficient to promote cancer susceptibility [33-35]. Although the complete loss of PTEN is observed more frequently in endometrial carcinoma and glioblastoma, it appears in less than $15 \%$ of prostate, breast, colon, and lung cancers. Even in the cancers with the highest biallelic mutation frequencies, monoallelic mutation and loss of protein expression are observed more commonly [15,36,37]. Germline mutations of PTEN are also associated with genetic disorders with an increased risk of cancer, collectively referred to as PTEN hamartoma syndromes (PHTS), which include Cowden syndrome, Bannayan-Zonana syndrome, Lhermitte-Duclos syndrome, Proteus syndrome, and Proteus-like syndrome [38]. The majority of germline mutations on PTEN 
are nonsense or frame-shift mutations and occur in the C-terminal region, resulting in premature stop codons and truncations of the protein in approximately $70 \%$ of the total mutations studied [38]. Experiments performed in GEM models have demonstrated that mice with tissue-specific Pten-knockout develop tumors in various organs, supporting the role of PTEN as a potent tumor suppressor $[31,39,40]$.

\section{Epigenetic, Transcriptional, and Post-Transcriptional Regulation of PTEN}

In addition to the frequent occurrence of PTEN mutations in various cancer types, PTEN levels are also downregulated at both transcriptional and post-transcriptional levels.

\subsection{Transcriptional Regulation of PTEN}

PTEN mRNA levels are regulated by several transcription factors. The p53 tumor suppressor upregulates PTEN expression in response to irradiation and other sources of DNA damage via direct binding to a cis-element in the PTEN promoter to trans-activate PTEN. The induction of p53 in cells elevates PTEN at both mRNA and protein levels in a variety of cell lines [41]. Loss of p53 caused a decrease in PTEN expression in mouse embryonic fibroblast (MEF) cells [42]. EGR1 upregulates Pten transcription by direct binding to a GCGGCGGCG site in the 5' untranslated region [43]. It has been reported that EGR1 levels predict PTEN expression and survival in non-small-cell lung cancer patients [44]. The EGR1-PTEN axis is correlated with tumor sensitivity to radiation, cell growth, invasion, and epithelial-mesenchymal transition (EMT) in various cancers [44-50]. Notch-1 signaling regulates the transcription of PTEN through the dual-function transcription factor CBF-1. In the absence of active Notch-1 signaling, CBF-1 binds to the PTEN promoter and represses PTEN expression. Overexpression of constitutively active Notch-1 converts CBF-1 into a transcriptional activator and induces PTEN expression in 293T cells and human prostate cancer cells [51-53]. Defects in Notch-1 signaling may contribute to the loss of PTEN expression in prostate adenocarcinoma [53]. PPAR $\gamma$ can bind two response elements located $23.3 \mathrm{~kb}$ upstream of PTEN and upregulate PTEN expression, thereby modulating allergic inflammation and tumor suppressor functions in inflammatory cells and some cancer cells [54-57]. The regulation of PTEN expression by NF- $\kappa B$ is not clearly delineated. The p50 and p65 subunits of NF- $\kappa B$ suppress PTEN expression through either direct or indirect mechanisms, while the p100 subunit stabilizes PTEN mRNA via inhibition of miR-494 [58-61]. JNK signaling can either induce or repress PTEN expression through its action on different downstream transcriptional factors, ATF-2 and c-Jun [62-64]. Previous research also suggests Bmi-1 and Snail1 repress PTEN expression $[65,66]$.

\subsection{Epigenetic Regulation of PTEN Expression}

Aberrant methylation of the PTEN promoter provides another mechanism for the loss of PTEN expression. Hypermethylation of CPG islands in the PTEN promoter is found in various types of cancers, including breast, lung, ovarian, cervical, colorectal, and thyroid cancer, as well as melanoma, gastric carcinoma, and metabolic syndrome [67-78]. In addition, SALL4 recruits the Mi-2/Nucleosome Remodeling and Deacetylase (NuRD) complex to the promoter region of PTEN, and represses PTEN transcription via the complex's histone deacetylase activity [79,80]. The blocking of SALL4 in glioma can alter PTEN expression and PI3K signaling [80]. Evi1 interacts with several polycomb complex proteins to form a repressive complex for PTEN downregulation, providing a novel epigenetic form of regulation of the PI3K pathway in leukemia [81].

\section{3. miRNA and PTEN Expression}

A number of miRNAs have been shown to participate in the regulation of biological processes by targeting PTEN. For example, Mir-21 binds to the 3'-UTR of PTEN mRNA and inhibits PTEN expression [82]. MiR-21 confers resistance to some chemotherapy drugs and radiation therapy in cancers [83-86]. This effect appears to be mediated via modulation of PTEN since downregulation of PTEN in the HCC cell attenuates the effects of anti-miR-21 on growth and invasion [82]. Similarly, application of the PI3K inhibitor LY294002 in gastric cancer cell line SGC7901 could abrogate 
miR-21-induced cell survival and resistance to chemotherapeutic agent cisplatin [83]. MiR-29 regulates PTEN in various ways. Previous research demonstrates that YAP1 downregulates PTEN by inducing MiR-29 to inhibit PTEN translation. In this case, PTEN knockdown mimics the YAP-induced increase in cell size and LY294002 treatment rescues the effect of YAP on cell size [87]. MiR-29a may confer the acquisition of resistance to adriamycin in breast cancer cells by the downregulation of PTEN and activation of the PI3K pathway [88]. The effect of MiR-29 on PTEN level is a cell type-dependent. Studies in hepatic stellate cells and liver fibrosis models suggest that MiR-29 upregulates PTEN expression by targeting DNA methyltransferases such as Dnmt1, Dnmt3b, and Set1a to prevent excess liver fibrosis $[89,90]$. Finally, the MiR-130 family downregulates PTEN to promote cell proliferation, invasion, migration, and EMT in cancer [91-93].

\subsection{Long Non-Coding RNA and PTEN Expression}

Long non-coding RNAs can upregulate PTEN expression either by functioning as a decoy for PTEN-targeting miRNAs or by altering PTEN promoter methylation. PTENP1 is a processed pseudogene with high homology to PTEN. PTENP1 is targeted by PTEN-targeting miRNAs, and can function as a competing endogenous RNA (ceRNA) to protect PTEN from miRNA recognition [94]. The stabilization of PTEN by PTENP1 inhibits cell proliferation, invasion, and migration in cancers [95-101]. Other long non-coding RNAs, including GAS5, FER1L4, XIST, MEG3, and NBAT, have also been reported to sequester miRNAs that specifically target PTEN, thereby stabilizing PTEN mRNA and modulating PTEN function [102-116]. The long non-coding RNA HOTAIR regulates PTEN expression via several different mechanisms [117-120]. Depletion of HOTAIR in laryngeal squamous cell carcinoma decreases PTEN methylation to reduce invasion and tumor growth [117]. HOTAIR can also upregulate PTEN expression by targeting miR-19, miR-29b, and miR-17-5- $p$ [118-120].

\section{Post-Translational Modifications of PTEN}

The activity, stability, and subcellular localization of PTEN can be regulated by several post-translational modifications (Table 1). The sections below will briefly discuss them.

Table 1. Post-translational modifications of PTEN.

\begin{tabular}{|c|c|c|}
\hline Modification & Modifier & Site \\
\hline \multirow{4}{*}{ phosphorylation } & CK2 [121-123] & S370, S385 [121-123] \\
\hline & GSK3 $\beta$ [124] & T366 [124] \\
\hline & & $\begin{array}{c}\text { T382, T383 [125] } \\
\text { S380, T382, T383 [126] } \\
\text { S380, T382, T383, T385 [127,128 }\end{array}$ \\
\hline & $\begin{array}{c}\text { FGFR,SRC family kinases [129] } \\
\text { FGFR2 [130] }\end{array}$ & Y240 [130,131] \\
\hline \multirow{5}{*}{ Ubiquitination } & Need4-1 [129,132,133] & $\mathrm{K} 13, \mathrm{~K} 289$ \\
\hline & CHIP [134] & K48 [134] \\
\hline & NRF146 [135] & \\
\hline & WWP1 $[138,139]$ & K27 [139] \\
\hline & XIAP [140] & \\
\hline Oxidation & $\begin{array}{c}\text { ROS [141,142] } \\
\text { Thioreductase [142] }\end{array}$ & C71, C124 [141,142] \\
\hline \multirow{3}{*}{ Acetylation } & PCAF [143] & K125, K128 [143] \\
\hline & CBP [144] & K402 [144] \\
\hline & HDAC6 [145] & K163 [145] \\
\hline S-nitrosylation & NO [146] & C83 [146] \\
\hline Ribosylation & TNKS1, TNKS2 [135] & \\
\hline Sumoylation & SUMO1 [147] & K266 [147] \\
\hline
\end{tabular}




\subsection{Phosphorylation}

The phosphorylation of PTEN has different functions on the activity, stability, and subcellular localization. CK2 phosphorylates several Ser (S)/Thr (T) residues in the C-terminal tail of PTEN to decrease the activity and increase the stability of PTEN [121,122]. The mutation of two CK2 phosphorylation sites, S370 and S385, to alanine, accelerates proteasome-mediated degradation of PTEN and partial proteolysis by caspase- $3[122,123]$. PTEN is also phosphorylated on T366 by GSK3 $\beta$. Blocking the phosphorylation of T366 by either mutation or GSK3 inhibition in glioblastoma cell lines led to a stabilization of the PTEN protein [124]. Dephosphorylation at T382 and T383 leads to an increase in the PTEN degradation rate and enhanced binding affinity to the PDZ2 domain of MAGI-2 [125]. H. pylori inactivates PTEN by inducing PTEN phosphorylation at residues S380/T382/T383, resulting in the enhanced survival of gastric epithelial cells [126]. The mutation of four phosphorylation sites in the C-terminal tail (S380, T382, T383, and S385) to alanine increases the membrane association of PTEN $[127,128]$. The phosphorylation of tyrosine 240 is frequently found in glioblastoma (GBM) patient samples $[130,131]$. A recent study suggested that ionizing radiation treatment induces Y240 phosphorylatoin of PTEN by FGFR2, which facilitates nuclear localization and chromatin binding of PTEN [130]. Y240 phosphorylation confers resistance to EGFR inhibition and ionizing radiation both in vitro and in vivo, and is associated with decreased overall survival in patients. Both fibroblast growth factor receptors and SRC family kinases mediate PTEN Y240 phosphorylation, which functions independently of the lipid phosphatase activity of PTEN $[130,131]$.

\subsection{Ubiquitination}

The activity and stability of PTEN has been reported to be down-regulated by monoubiquitination and polyubiquitination. Two main monoubiquitination sites, K13 and K289, are important for PTEN nuclear localization and stability [129]. Nedd4-1 has been reported to ubiquitinate PTEN, thus regulating its stability and nuclear localization $[129,132,133]$. Another study found that Nedd4-1 is dispensable for the regulation of PTEN stability and localization in MEF and 293T cells, suggesting the regulation may act in a cell type and tissue specific manner [148]. The regulation of PTEN monoand polyubiquitination involves multiple ubiquitin ligases. CHIP and RNF-146 are two additional candidate E3 ligases for PTEN $[134,135]$. WWP2 physically interacts with PTEN and mediates its degradation through a ubiquitination-dependent pathway $[136,137]$. PTEN protein levels are also elevated in WWP1-depleted cells [138]. WWP1 mediates the polyubiquitination of PTEN at K27, thus suppressing the dimerization, membrane recruitment, and function of PTEN [138,139]. XIAP also promotes PTEN ubiquitination and degradation. Upregulation of XIAP by TGF- $\beta 3$ causes a reduction of PTEN in both the cytosol and the nucleus [140].

\subsection{Oxidation}

The Cys124 residue of PTEN forms a disulfide bond with Cys71 in response to oxidation by both endogenous and exogenous hydrogen peroxide, leading to the reversible inactivation of the lipid phosphatase function of PTEN [141,142]. In pancreatic cancer cells expressing COX-2 or 5-LOX, PTEN is oxidized and inactivated via arachidonic acid (AA) metabolism [149]. Several proteins are thought to be involved in the regulation of PTEN oxidation. Txnip ablation increases PTEN oxidation by thioredoxin NADP $(\mathrm{H})$ reduction [150]. AIF directly interacts with PTEN and prevents oxidative inactivation [151].

\subsection{Acetylation}

PCAF mediates acetylation of PTEN at lysine 125 and 128 to inhibit its activity in the regulation of the PI3K/AKT pathway [143]. The acetylation of PTEN at lysine 402 by CBP facilitates its interaction with PDZ domain-containing proteins [144]. Application of two non-selective HDAC inhibitors, 
TSA and suberoylanilide hydroxamic acid (SAHA), induced PTEN membrane translocation through PTEN acetylation at K163 by inhibiting HDAC6 [145].

\subsection{S-Nitrosylation}

Nitric oxide regulates the activity of PTEN via S-nitrosylation during transient global ischemia in the rat hippocampus [152]. The S-nitrosylation of PTEN at C83 inhibits the enzymatic activity of PTEN [146]. PARK2 depletion contributes to AMPK-mediated activation of endothelial nitric oxide synthase (eNOS), promoting both S-nitrosylation and ubiquitination of PTEN [153,154]. NOS1 prevents excessive autophagy and promotes the survival of nasopharyngeal carcinoma cells through the S-nitrosylation of PTEN [155].

\subsection{Ribosylation}

TNKS1 and TNKS2 interact with and ribosylate PTEN, which promotes the recognition of PTEN by RNF146, leading to PTEN ubiquitination and degradation [135].

\subsection{Sumoylation}

The SUMO1 modification of PTEN at Lys266 in its C2 domain was shown to increase the localization of PTEN at the plasma membrane, resulting in the suppression of the PI3K-AKT pathway signaling and inhibition of anchorage-independent cell growth and tumor growth in vivo [147].

\section{Mechanisms of PI3K Activation in PTEN-Null Tumor Cells}

The loss of PTEN in a tumor amounts to removing the brake on PI3K signaling (Figure 1). However, exactly which PI3K isoforms and mechanisms are involved in the activation of the PI3K pathway in PTEN-null cells can vary from tumor to tumor. Thus, in preclinical models of tumors featuring PTEN loss accompanied by expression of oncogenes or activated RTKs, p110 $\alpha$ was found to be the major source of PI3K signaling [156]. Due to p110 $\alpha$ 's high specific activity and specific binding to Ras proteins, the result is hardly surprising [157]. However, in GEM tumor models driven by the knockout of PTEN and in a number of PTEN-null human tumor cell lines lacking expression of oncogenes or activated RTKs, p110 $\beta$ is often the major source of PI3K signaling $[19,20,158]$. It is remarkable that the less active isoform is generating the PI3K signal in response to PTEN loss in these models.

To address this question, Cizmecioglu et al. first examined how $\mathrm{p} 110 \beta$ is activated under physiological conditions by GPCRs [159]. Since the plasma membrane is the major site of PI3K activation and integration of divergent growth factor signals, the authors initially aimed to understand how spatial compartmentalization in the plasma membrane might contribute to the functions of the ubiquitous class IA PI3K isoforms, $\mathrm{p} 110 \alpha$ and $\mathrm{p} 110 \beta$. GPCRs, which are known to signal via p110 $\beta$, are localized in lipid rafts. Cizmecioglu et al. reported that binding of Rac1, a known binding protein of $\mathrm{p} 110 \beta$, was necessary to localize $\mathrm{p} 110 \beta$ to membrane rafts, which increases the likelihood of its activation by GPCR. On the other hand, $\mathrm{p} 110 \alpha$, which is not associated with GPCR signaling, was found in non-raft regions of the plasma membrane. Interestingly, when $\mathrm{p} 110 \alpha$ was artificially tagged to direct it to rafts, GPCRs were able to mediate the activation of AKT via p110 $\alpha$. It had also been previously shown that upon $\mathrm{PIP}_{3}$ production, raft nanodomains were involved in recruiting AKT to the plasma membrane [160]. Cizmecioglu et al. further demonstrated that $\mathrm{p} 110 \beta$-dependent PTEN-null tumor cells critically rely on raft-associated PI3K signaling [159]. A unique positive feedback loop was suggested in which p110 $\beta$ is localized for activation by Rac [161] and Rac in turn is activated by $\mathrm{PIP}_{3}$ via $\mathrm{PIP}_{3}$-activated guanine-nucleotide exchange factors (GEFs) $[162,163]$. In other words, $\mathrm{p} 110 \beta$ and Rac form a positive feedback loop to generate the key signals associated with Pten loss that leads to cell proliferation and migration (Figure 1). 


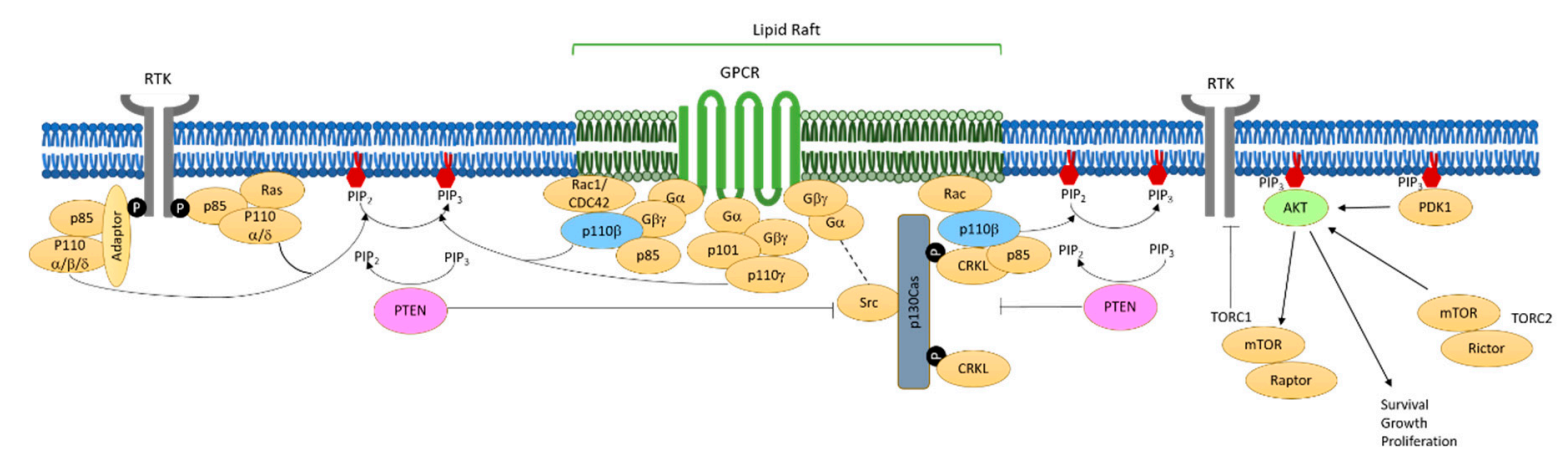

Figure 1. Overview of PI3K-AKT signaling pathway. Class I PI3Ks are heterodimers composed of a catalytic subunit (p110) and a regulatory subunit (p85 or p101). Once activated by cell surface receptors, PI3Ks phosphorylate $\mathrm{PIP}_{2}$ to $\mathrm{PIP}_{3}$, which activates AKT for cell survival, growth, and proliferation. PTEN is the main negative regulator of the signaling pathway. PTEN-null tumor cells often rely on $\mathrm{p} 110 \mathrm{~b}$ for PI3K signaling, and the figure above depicts the potential mechanism of $\mathrm{p} 110 \mathrm{~b}$ activation via CRKL/p130Cas/Src/Rac, which results in their localization in lipid rafts in the absence of PTEN.

The data on the Rac/p110 $\beta$ feedback loop described above (see [161] for details) leave open a big question: How is the feedback loop activated in the first place? Or, more specifically, what is initially activating p110 $\beta$ in PTEN-null tumors? While in theory this could be achieved via interactions with G $\beta \gamma$ subunits of GPCRs, as is the case physiologically, previous data suggests this is often not true for PTEN-null tumors [159]. One clue to the identity of the mechanism providing the "foot on the accelerator" of the PI3K pathway was found by a proteomic screen for new p110 $\beta$-interacting proteins. CRKL was identified as a protein preferentially associated with p110 $\beta$ [164]. Mechanistic studies by Zhang et al. revealed that, in addition to $\mathrm{p} 110 \beta, \mathrm{CRKL}$ binds to $\mathrm{p} 130 \mathrm{Cas}$, which is, in turn, activated via phosphorylation by Src $[165,166]$. The depletion of CRKL was found to downregulate p110 $\beta$-dependent PI3K signaling in PTEN-deficient cancer cells. Zhang et al. suggested that a PTEN/FAK/Src/p130Cas axis may activate CRKL/p110 $\beta$ [164]. The cooperation of Src inhibition with p110 $\beta$ inhibition to suppress the growth of PTEN-null cells was also demonstrated. Significantly, the data indicate a potential mechanism behind the link between PTEN loss and p110 $\beta$ activation.

Additionally, there may be an interesting feedback loop connecting YAP activation, PTEN loss, and p110 $\beta$ activation. As previously mentioned, YAP activation decreases PTEN expression via miR-29 [87]. Activation of YAP also directly increases p110 $\beta$ expression through TEAD [167]. Reciprocally, p110 $\beta$ activation via PTEN loss is known to activate Rac, which in turn can activate YAP $[159,168]$. Thus, there exists a putative positive feedback loop in which $p 110 \beta$ activates YAP via Rac and, once activated, YAP in turn increases p110 $\beta$ expression and potential activity. Notably, a signature of YAP activation is seen in the set of PTEN mutant cell lines which are sensitive to the p110 $\beta$ inhibitor KIN-193 [169].

\section{Turning Mechanistic Insights into Possible Therapies}

Early clinical trials with so-called pan-PI3K inhibitors were unimpressive for most PTEN-null tumor indications $[170,171]$. This is likely because early pan-inhibitors such as BKM120 and GDC-0941 were roughly 10-20 times more potent on $\mathrm{p} 110 \alpha$ than $\mathrm{p} 110 \beta$. However, recent trials have begun using p110ß-targeted compounds such as AZD8186 (NCT01884285) and GSK2636771 (NCT01458067), and early results are more promising [172,173]. An AKT inhibitor from Genentech, GDC-0068, has also had promising early results in PTEN-null tumors [174].

Inevitably, single agent therapies are likely to have only short-lasting effects in solid tumors. Hence, preclinical research is now focused on finding combination therapies, largely building on p110 $\beta$ inhibitors. Unlike compounds that target $\mathrm{p} 110 \alpha$, which have shown high on-target toxicity due to effects on insulin signaling, a pure p110 $\beta$ inhibitor is expected to have relatively low on-target adverse effects. Indeed a mouse with whole-body knock-in of a kinase-dead allele of p110 $\beta$ is 
fairly healthy with only relatively minor insulin resistance [175]. One example of a combination therapy studied is the combination of a p110 $\beta$ inhibitor and a Src inhibitor targeting the signaling cascade of Src/p130Cas/CRKL/p110 $\beta$. The results showed suppressed growth of PTEN-null human cancer cells [164]. Another example is a study which found that PTEN loss suppresses androgen receptor transcription factor activity and androgen-responsive gene expression, thereby promoting castration-resistant prostate cancer (CRPC) development [176]. Based on the pre-clinical study, androgen deprivation therapy accompanied by a $\mathrm{p} 110 \beta$ inhibitor may prove to be beneficial in treating CRPC. In fact, there is an ongoing clinical trial (NCT02215096) that combines a p110 $\beta$ inhibitor with an antiandrogen in treatment of metastatic CRPC [177].

\subsection{Combining $p 110 \beta$ Inhbition and Immunotherapies}

Recently, exciting new roles of PTEN in immune regulation and inflammatory diseases have been discovered. PTEN has been found to play important roles in both T cells and in cloaking tumors from the immune system. A study in mice demonstrated that the T cell-specific loss of PTEN in mice causes defects in central and peripheral tolerance and increase susceptibility to $\mathrm{T}$ cell lymphoma and leukemia [178]. More exciting in terms of therapeutic implications is the tumor cell-specific role of PTEN in the tumors' interaction with the immune system. In a recent paper, the loss of PTEN in patients was found to be correlated with reduced $\mathrm{T}$ cell infiltration at tumor sites and a poorer response to PD-1 blockade therapy [179]. In this study, Peng et al. showed that the loss of PTEN in tumor cells boosted the level of immunosuppressive cytokines, creating a microenvironment that allows tumor cells to escape from $T$ cell-mediated cell death. In a follow-up pre-clinical study, the group demonstrated that a combination of an OX40 agonist antibody and a p110 $\beta$ inhibitor induce robust and durable anti-tumor $\mathrm{T}$ cell immunity in melanoma mouse models [180]. Furthermore, a clinical study (NCT03131908) is in progress that combines a p110 $\beta$ inhibitor with an anti-PD-1 antibody in patients with metastatic melanoma and PTEN loss [181]. Thus, it is likely that the most effective treatment for PTEN null tumors will involve a combination of targeted therapies, such as p110 $\beta$ inhibitors and immunotherapies.

\subsection{PTEN-Deficient Synthetic Lethality}

Synthetic lethality is said to occur for two genes when alteration in either gene alone does not affect cell viability but perturbation of both genes at the same time leads to cell death. The concept of synthetic lethality can be applied to cancer therapy by inhibiting one protein activity in cancer cell harboring a loss of function mutation of the second gene to induce cell death [182]. Numerous examples of synthetic lethality have been reported for PTEN. Homologous recombination is deficient in PTEN null human tumor cells, which sensitizes the cells to poly ADP-ribose polymerase (PARP) inhibitors [183]. Similarly, knockdown of $C H D 1$ inhibits cell growth in PTEN-null prostate cancer cells while it has minimal effect in PTEN-intact cell lines [184]. RAD51 is a key regulator involved in DNA double strand break repair and homology-directed repair. Treatment of PTEN-deficient glioma cells with a cell-penetrating antibody against RAD51, 3E10, leads to an accumulation of DNA damage causing decreased proliferation and increased cell death compared to isogenic PTEN-proficient controls [185]. ITGA5 knockdown and the pharmacologic inhibition of BCL2-BCLX $\mathrm{L}_{\mathrm{L}}$ had a synergistic effect with PI3K/AKT inhibitors in PTEN-mutant prostate cancer cells, such as LNCap and PC3, but not in PTEN-proficient DU145 cells [186]. The ATM kinase inhibitor, KU-60019, preferentially sensitizes PTEN-deficient MDA-MB-468 breast cancer cells to cisplatin, while only slightly enhancing sensitivity of PTEN-wild type breast cancer cells [187]. BRG1 was identified in a CRISPR-Cas9-based screen in 22RV-1 cells for epigenetic regulators specifically required in PTEN-deficient PCa cells. The BRG1 antagonist, PFI-3, inhibits PTEN-deficient tumor progression [188]. In PTEN-null GBM models, LOX inhibition markedly suppresses macrophage infiltration and tumor progression [189]. Finally, the metabolic regulator, pyruvate dehydrogenase kinase 1 , was identified as a synthetic-essential gene and potential therapeutic target in PTEN-deficient cancers [190]. 


\subsection{Reactivation of PTEN}

Recent research suggested that it is possible to reactivate PTEN expression/activity for cancer treatment $[48,139,191]$. Thus, HDAC inhibition induces increased PTEN levels in an EGR1-dependent manner, promoting apoptosis in synovial sarcoma [48]. Oxidized PTEN is preferentially reactivated by the thioredoxin system. This PTEN reactivation was inhibited by inducible depletion of thioredoxin 1 in intact living cells [191]. In a recent paper, researchers found that indole-3-carbinol (I3C) was able to inhibit WWP1-mediated PTEN K27-linked polyubiquitination both both in vitro and in vivo. Since WWP1 expression is regulated by MYC, I3C treatment may be especially effective in tumors driven by MYC [139].

\section{Conclusions and Perspective}

Tumors lacking the PTEN expression comprise one of the largest tumor classes. Despite the fact that PTEN loss results in abnormally high PI3K pathway activation, therapeutic approaches to this tumor class have been disappointing. Historically, the development of anti-cancer therapeutics targeting tumor suppressors has been particularly challenging. In the case of PTEN, this challenge has been exacerbated by the multiple functions of the PTEN protein and its highly complex modes of regulation. However, with the advent of $\mathrm{p} 110 \beta$-selective PI3K inhibitors and promising combinations of these inhibitors with both targeted and immunotherapies, it can be hoped for that a more favorable outlook for patients with PTEN-null tumors is on the horizon.

Funding: This research was funded by NIH grants to T.M.R. (R01 CA187918 and R01233810) and by the Intramural Research Program of Korea Institute of Science and Technology (2E27960).

Conflicts of Interest: T.M.R. has a consulting relationship with Novartis, is a founder of Crimson Biotech and Geode Therapeutics, and is a member of the corporate boards of iKang Healthcare, Crimson Biotech, and Geode Therapeutics.

\section{References}

1. Engelman, J.A.; Luo, J.; Cantley, L.C. The evolution of phosphatidylinositol 3-kinases as regulators of growth and metabolism. Nat. Rev. Genet. 2006, 7, 606-619. [CrossRef] [PubMed]

2. Liu, P.; Cheng, H.; Roberts, T.M.; Zhao, J.J. Targeting the phosphoinositide 3-kinase pathway in cancer. Nat. Rev. Drug Discov. 2009, 8, 627-644. [CrossRef] [PubMed]

3. Chantry, D.; Vojtek, A.; Kashishian, A.; Holtzman, D.A.; Wood, C.; Gray, P.W.; Cooper, J.A.; Hoekstra, M.F. p110delta, a novel phosphatidylinositol 3-kinase catalytic subunit that associates with p85 and is expressed predominantly in leukocytes. J. Biol. Chem. 1997, 272, 19236-19241. [CrossRef] [PubMed]

4. Vanhaesebroeck, B.; Welham, M.J.; Kotani, K.; Stein, R.; Warne, P.H.; Zvelebil, M.J.; Higashi, K.; Volinia, S.; Downward, J.; Waterfield, M.D. P110delta, a novel phosphoinositide 3-kinase in leukocytes. Proc. Natl. Acad. Sci. USA 1997, 94, 4330-4335. [CrossRef]

5. Kaneda, M.M.; Messer, K.S.; Ralainirina, N.; Li, H.; Leem, C.J.; Gorjestani, S.; Woo, G.; Nguyen, A.V.; Figueiredo, C.C.; Foubert, P.; et al. PI3K $\gamma$ is a molecular switch that controls immune suppression. Nature 2016, 539, 437-442. [CrossRef]

6. Li, J.; Yen, C.; Liaw, D.; Podsypanina, K.; Bose, S.; Wang, S.I.; Puc, J.; Miliaresis, C.; Rodgers, L.; McCombie, R.; et al. PTEN, a putative protein tyrosine phosphatase gene mutated in human brain, breast, and prostate cancer. Science 1997, 275, 1943-1947. [CrossRef]

7. Liaw, D.; Marsh, D.J.; Li, J.; Dahia, P.L.; Wang, S.I.; Zheng, Z.; Bose, S.; Call, K.M.; Tsou, H.C.; Peacocke, M.; et al. Germline mutations of the PTEN gene in Cowden disease, an inherited breast and thyroid cancer syndrome. Nat. Gene. 1997, 16, 64-67. [CrossRef]

8. Steck, P.A.; Pershouse, M.A.; Jasser, S.A.; Yung, W.K.; Lin, H.; Ligon, A.H.; Langford, L.A.; Baumgard, M.L.; Hattier, T; Davis, T.; et al. Identification of a candidate tumour suppressor gene, MMAC1, at chromosome 10q23.3 that is mutated in multiple advanced cancers. Nat. Gene. 1997, 15, 356-362. [CrossRef]

9. Zhang, X.C.; Piccini, A.; Myers, M.P.; Van Aelst, L.; Tonks, N.K. Functional analysis of the protein phosphatase activity of PTEN. Biochem. J. 2012, 444, 457-464. [CrossRef] 
10. Leslie, N.R.; Downes, C.P. PTEN: The down side of PI 3-kinase signalling. Cell Signal. 2002, 14, $285-295$. [CrossRef]

11. Planchon, S.M.; Waite, K.A.; Eng, C. The nuclear affairs of PTEN. J. Cell Sci. 2008, 121, 249-253. [CrossRef] [PubMed]

12. Gil, A.; Andres-Pons, A.; Fernandez, E.; Valiente, M.; Torres, J.; Cervera, J.; Pulido, R. Nuclear localization of PTEN by a Ran-dependent mechanism enhances apoptosis: Involvement of an N-terminal nuclear localization domain and multiple nuclear exclusion motifs. Mol. Biol. Cell 2006, 17, 4002-4013. [CrossRef] [PubMed]

13. Yin, Y.; Shen, W.H. PTEN: A new guardian of the genome. Oncogene 2008, 27, 5443-5453. [CrossRef] [PubMed]

14. Thorpe, L.M.; Yuzugullu, H.; Zhao, J.J. PI3K in cancer: Divergent roles of isoforms, modes of activation and therapeutic targeting. Nat. Rev. Cancer 2015, 15, 7-24. [CrossRef] [PubMed]

15. Leslie, N.R.; Downes, C.P. PTEN function: How normal cells control it and tumour cells lose it. Biochem. J. 2004, 382, 1-11. [CrossRef]

16. Berns, K.; Horlings, H.M.; Hennessy, B.T.; Madiredjo, M.; Hijmans, E.M.; Beelen, K.; Linn, S.C.; Gonzalez-Angulo, A.M.; Stemke-Hale, K.; Hauptmann, M.; et al. A Functional Genetic Approach Identifies the PI3K Pathway as a Major Determinant of Trastuzumab Resistance in Breast Cancer. Cancer Cell 2007, 12, 395-402. [CrossRef]

17. Utermark, T.; Rao, T.; Cheng, H.; Wang, Q.; Lee, S.H.; Wang, Z.C.; Iglehart, J.D.; Roberts, T.M.; Muller, W.J.; Zhao, J.J. The p110alpha and p110beta isoforms of PI3K play divergent roles in mammary gland development and tumorigenesis. Genes Dev. 2012, 26, 1573-1586. [CrossRef]

18. Tsolakos, N.; Durrant, T.N.; Chessa, T.; Suire, S.M.; Oxley, D.; Kulkarni, S.; Downward, J.; Perisic, O.; Williams, R.L.; Stephens, L.; et al. Quantitation of class IA PI3Ks in mice reveals p110-free-p85s and isoform-selective subunit associations and recruitment to receptors. Proc. Natl. Acad. Sci. USA 2018, 115, 12176-12181. [CrossRef]

19. Wee, S.; Wiederschain, D.; Maira, S.M.; Loo, A.; Miller, C.; de Beaumont, R.; Stegmeier, F.; Yao, Y.M.; Lengauer, C. PTEN-deficient cancers depend on PIK3CB. Proc. Natl. Acad. Sci. USA 2008, 105, 13057-13062. [CrossRef]

20. Jia, S.; Liu, Z.; Zhang, S.; Liu, P.; Zhang, L.; Lee, S.H.; Zhang, J.; Signoretti, S.; Loda, M.; Roberts, T.M.; et al. Essential roles of PI(3)K-p110beta in cell growth, metabolism and tumorigenesis. Nature 2008, 454, 776-779. [CrossRef]

21. Cerami, E.; Gao, J.; Dogrusoz, U.; Gross, B.E.; Sumer, S.O.; Aksoy, B.A.; Jacobsen, A.; Byrne, C.J.; Heuer, M.L.; Larsson, E.; et al. The cBio cancer genomics portal: An open platform for exploring multidimensional cancer genomics data. Cancer Discov. 2012, 2, 401-404. [CrossRef] [PubMed]

22. Gao, J.; Aksoy, B.A.; Dogrusoz, U.; Dresdner, G.; Gross, B.; Sumer, S.O.; Sun, Y.; Jacobsen, A.; Sinha, R.; Larsson, E.; et al. Integrative analysis of complex cancer genomics and clinical profiles using the cBioPortal. Sci. Signal. 2013, 6, 11. [CrossRef] [PubMed]

23. Millis, S.Z.; Ikeda, S.; Reddy, S.; Gatalica, Z.; Kurzrock, R. Landscape of Phosphatidylinositol-3-Kinase Pathway Alterations Across 19784 Diverse Solid Tumors. JAMA Oncol. 2016, 2, 1565-1573. [CrossRef] [PubMed]

24. Schade, B.; Rao, T.; Dourdin, N.; Lesurf, R.; Hallett, M.; Cardiff, R.D.; Muller, W.J. PTEN deficiency in a luminal ErbB-2 mouse model results in dramatic acceleration of mammary tumorigenesis and metastasis. J. Biol. Chem. 2009, 284, 19018-19026. [CrossRef]

25. Chalhoub, N.; Baker, S.J. PTEN and the PI3-kinase pathway in cancer. Annu. Rev. Pathol. 2009, 4, 127-150. [CrossRef]

26. Salmena, L.; Carracedo, A.; Pandolfi, P.P. Tenets of PTEN tumor suppression. Cell 2008, 133, $403-414$. [CrossRef]

27. Bignell, G.R.; Greenman, C.D.; Davies, H.; Butler, A.P.; Edkins, S.; Andrews, J.M.; Buck, G.; Chen, L.; Beare, D.; Latimer, C.; et al. Signatures of mutation and selection in the cancer genome. Nature 2010, 463, 893-898. [CrossRef]

28. Song, M.S.; Salmena, L.; Pandolfi, P.P. The functions and regulation of the PTEN tumour suppressor. Nat. Rev. Mol. Cell Biol. 2012, 13, 283-296. [CrossRef]

29. Bonneau, D.; Longy, M. Mutations of the human PTEN gene. Hum. Mutat. 2000, 16, 109-122. [CrossRef] 
30. Georgescu, M.M.; Kirsch, K.H.; Kaloudis, P.; Yang, H.; Pavletich, N.P.; Hanafusa, H. Stabilization and productive positioning roles of the C2 domain of PTEN tumor suppressor. Cancer Res. 2000, 60, 7033-7038.

31. Di Cristofano, A.; Pesce, B.; Cordon-Cardo, C.; Pandolfi, P.P. Pten is essential for embryonic development and tumour suppression. Nat. Gene. 1998, 19, 348-355. [CrossRef]

32. Podsypanina, K.; Ellenson, L.H.; Nemes, A.; Gu, J.; Tamura, M.; Yamada, K.M.; Cordon-Cardo, C.; Catoretti, G.; Fisher, P.E.; Parsons, R. Mutation of Pten/Mmac1 in mice causes neoplasia in multiple organ systems. Proc. Natl. Acad. Sci. USA 1999, 96, 1563-1568. [CrossRef]

33. Alimonti, A.; Carracedo, A.; Clohessy, J.G.; Trotman, L.C.; Nardella, C.; Egia, A.; Salmena, L.; Sampieri, K.; Haveman, W.J.; Brogi, E.; et al. Subtle variations in Pten dose determine cancer susceptibility. Nat. Genet. 2010, 42, 454-458. [CrossRef]

34. Trotman, L.C.; Niki, M.; Dotan, Z.A.; Koutcher, J.A.; Di Cristofano, A.; Xiao, A.; Khoo, A.S.; Roy-Burman, P.; Greenberg, N.M.; Van Dyke, T.; et al. Pten dose dictates cancer progression in the prostate. PLoS Biol. 2003, 1, 59. [CrossRef]

35. Kwabi-Addo, B.; Giri, D.; Schmidt, K.; Podsypanina, K.; Parsons, R.; Greenberg, N.; Ittmann, M. Haploinsufficiency of the Pten tumor suppressor gene promotes prostate cancer progression. Proc. Natl. Acad. Sci. USA 2001, 98, 11563-11568. [CrossRef]

36. Zhou, X.P.; Loukola, A.; Salovaara, R.; Nystrom-Lahti, M.; Peltomaki, P.; de la Chapelle, A.; Aaltonen, L.A.; Eng, C. PTEN mutational spectra, expression levels, and subcellular localization in microsatellite stable and unstable colorectal cancers. Am. J. Pathol. 2002, 161, 439-447. [CrossRef]

37. Ali, I.U.; Schriml, L.M.; Dean, M. Mutational spectra of PTEN/MMAC1 gene: A tumor suppressor with lipid phosphatase activity. J. Natl. Cancer Inst. 1999, 91, 1922-1932. [CrossRef]

38. Bubien, V.; Bonnet, F.; Brouste, V.; Hoppe, S.; Barouk-Simonet, E.; David, A.; Edery, P.; Bottani, A.; Layet, V.; Caron, O.; et al. High cumulative risks of cancer in patients with PTEN hamartoma tumour syndrome. J. Med. Genet. 2013, 50, 255-263. [CrossRef]

39. Knobbe, C.B.; Lapin, V.; Suzuki, A.; Mak, T.W. The roles of PTEN in development, physiology and tumorigenesis in mouse models: A tissue-by-tissue survey. Oncogene 2008, 27, 5398-5415. [CrossRef]

40. Suzuki, A.; de la Pompa, J.L.; Stambolic, V.; Elia, A.J.; Sasaki, T.; del Barco Barrantes, I.; Ho, A.; Wakeham, A.; Itie, A.; Khoo, W.; et al. High cancer susceptibility and embryonic lethality associated with mutation of the PTEN tumor suppressor gene in mice. Curr. Biol. 1998, 8, 1169-1178. [CrossRef]

41. Stambolic, V.; MacPherson, D.; Sas, D.; Lin, Y.; Snow, B.; Jang, Y.; Benchimol, S.; Mak, T.W. Regulation of PTEN transcription by p53. Mol. Cell 2001, 8, 317-325. [CrossRef]

42. Wang, J.; Ouyang, W.; Li, J.; Wei, L.; Ma, Q.; Zhang, Z.; Tong, Q.; He, J.; Huang, C. Loss of tumor suppressor p53 decreases PTEN expression and enhances signaling pathways leading to activation of activator protein 1 and nuclear factor kappaB induced by UV radiation. Cancer Res. 2005, 65, 6601-6611. [CrossRef]

43. Virolle, T.; Adamson, E.D.; Baron, V.; Birle, D.; Mercola, D.; Mustelin, T.; de Belle, I. The Egr-1 transcription factor directly activates PTEN during irradiation-induced signalling. Nat. Cell Biol. 2001, 3, 1124-1128. [CrossRef]

44. Ferraro, B.; Bepler, G.; Sharma, S.; Cantor, A.; Haura, E.B. EGR1 predicts PTEN and survival in patients with non-small-cell lung cancer. J. Clin. Oncol. 2005, 23, 1921-1926. [CrossRef]

45. Baron, V.; Adamson, E.D.; Calogero, A.; Ragona, G.; Mercola, D. The transcription factor Egr1 is a direct regulator of multiple tumor suppressors including TGFbeta1, PTEN, p53, and fibronectin. Cancer Gene Ther. 2006, 13, 115-124. [CrossRef]

46. Yu, J.; Zhang, S.S.; Saito, K.; Williams, S.; Arimura, Y.; Ma, Y.; Ke, Y.; Baron, V.; Mercola, D.; Feng, G.S.; et al. PTEN regulation by Akt-EGR1-ARF-PTEN axis. EMBO J. 2009, 28, 21-33. [CrossRef]

47. Yamamoto, C.; Basaki, Y.; Kawahara, A.; Nakashima, K.; Kage, M.; Izumi, H.; Kohno, K.; Uramoto, H.; Yasumoto, K.; Kuwano, M.; et al. Loss of PTEN expression by blocking nuclear translocation of EGR1 in gefitinib-resistant lung cancer cells harboring epidermal growth factor receptor-activating mutations. Cancer Res. 2010, 70, 8715-8725. [CrossRef]

48. Su, L.; Cheng, H.; Sampaio, A.V.; Nielsen, T.O.; Underhill, T.M. EGR1 reactivation by histone deacetylase inhibitors promotes synovial sarcoma cell death through the PTEN tumor suppressor. Oncogene 2010, 29, 4352-4361. [CrossRef]

49. Lau, M.T.; Klausen, C.; Leung, P.C. E-cadherin inhibits tumor cell growth by suppressing PI3K/Akt signaling via beta-catenin-Egr1-mediated PTEN expression. Oncogene 2011, 30, 2753-2766. [CrossRef] 
50. Kim, J.; Kang, H.S.; Lee, Y.J.; Lee, H.J.; Yun, J.; Shin, J.H.; Lee, C.W.; Kwon, B.M.; Hong, S.H. EGR1-dependent PTEN upregulation by 2-benzoyloxycinnamaldehyde attenuates cell invasion and EMT in colon cancer. Cancer Lett. 2014, 349, 35-44. [CrossRef]

51. Chappell, W.H.; Green, T.D.; Spengeman, J.D.; McCubrey, J.A.; Akula, S.M.; Bertrand, F.E. Increased protein expression of the PTEN tumor suppressor in the presence of constitutively active Notch-1. Cell Cycle 2005, 4, 1389-1395. [CrossRef] [PubMed]

52. Whelan, J.T.; Forbes, S.L.; Bertrand, F.E. CBF-1 (RBP-J kappa) binds to the PTEN promoter and regulates PTEN gene expression. Cell Cycle 2007, 6, 80-84. [CrossRef] [PubMed]

53. Whelan, J.T.; Kellogg, A.; Shewchuk, B.M.; Hewan-Lowe, K.; Bertrand, F.E. Notch-1 signaling is lost in prostate adenocarcinoma and promotes PTEN gene expression. J. Cell Biochem. 2009, 107, 992-1001. [CrossRef]

54. Patel, L.; Pass, I.; Coxon, P.; Downes, C.P.; Smith, S.A.; Macphee, C.H. Tumor suppressor and anti-inflammatory actions of PPARgamma agonists are mediated via upregulation of PTEN. Curr. Biol. 2001, 11, 764-768. [CrossRef]

55. Farrow, B.; Evers, B.M. Activation of PPARgamma increases PTEN expression in pancreatic cancer cells. Biochem. Bio. Res. Commun. 2003, 301, 50-53. [CrossRef]

56. Lee, K.S.; Park, S.J.; Hwang, P.H.; Yi, H.K.; Song, C.H.; Chai, O.H.; Kim, J.S.; Lee, M.K.; Lee, Y.C. PPAR-gamma modulates allergic inflammation through up-regulation of PTEN. FASEB J. 2005, 19, 1033-1035. [CrossRef]

57. Teresi, R.E.; Shaiu, C.W.; Chen, C.S.; Chatterjee, V.K.; Waite, K.A.; Eng, C. Increased PTEN expression due to transcriptional activation of PPARgamma by Lovastatin and Rosiglitazone. Int. J. Cancer 2006, 118, 2390-2398. [CrossRef]

58. Vasudevan, K.M.; Gurumurthy, S.; Rangnekar, V.M. Suppression of PTEN expression by NF-kappa B prevents apoptosis. Mol. Cell Biol. 2004, 24, 1007-1021. [CrossRef]

59. Xia, D.; Srinivas, H.; Ahn, Y.H.; Sethi, G.; Sheng, X.; Yung, W.K.; Xia, Q.; Chiao, P.J.; Kim, H.; Brown, P.H.; et al. Mitogen-activated protein kinase kinase-4 promotes cell survival by decreasing PTEN expression through an NF kappa B-dependent pathway. J. Boil. Chem. 2007, 282, 3507-3519. [CrossRef]

60. Ghosh-Choudhury, N.; Mandal, C.C.; Ghosh-Choudhury, N.; Ghosh Choudhury, G. Simvastatin induces derepression of PTEN expression via NFkappaB to inhibit breast cancer cell growth. Cell Signal. 2010, 22, 749-758. [CrossRef]

61. Wang, Y.; Xu, J.; Gao, G.; Li, J.; Huang, H.; Jin, H.; Zhu, J.; Che, X.; Huang, C. Tumor-suppressor NFkappaB2 p100 interacts with ERK2 and stabilizes PTEN mRNA via inhibition of miR-494. Oncogene 2016, 35, 4080-4090. [CrossRef] [PubMed]

62. Wang, X.L.; Zhang, L.; Youker, K.; Zhang, M.X.; Wang, J.; LeMaire, S.A.; Coselli, J.S.; Shen, Y.H. Free fatty acids inhibit insulin signaling-stimulated endothelial nitric oxide synthase activation through upregulating PTEN or inhibiting Akt kinase. Diabetes 2006, 55, 2301-2310. [CrossRef] [PubMed]

63. Shen, Y.H.; Zhang, L.; Gan, Y.; Wang, X.; Wang, J.; LeMaire, S.A.; Coselli, J.S.; Wang, X.L. Up-regulation of PTEN (phosphatase and tensin homolog deleted on chromosome ten) mediates p38 MAPK stress signal-induced inhibition of insulin signaling. A cross-talk between stress signaling and insulin signaling in resistin-treated human endothelial cells. J. Biol. Chem. 2006, 281, 7727-7736. [CrossRef]

64. Hettinger, K.; Vikhanskaya, F.; Poh, M.K.; Lee, M.K.; de Belle, I.; Zhang, J.T.; Reddy, S.A.; Sabapathy, K. c-Jun promotes cellular survival by suppression of PTEN. Cell Death Differ. 2007, 14, 218-229. [CrossRef]

65. Song, L.B.; Li, J.; Liao, W.T.; Feng, Y.; Yu, C.P.; Hu, L.J.; Kong, Q.L.; Xu, L.H.; Zhang, X.; Liu, W.L.; et al. The polycomb group protein Bmi-1 represses the tumor suppressor PTEN and induces epithelial-mesenchymal transition in human nasopharyngeal epithelial cells. J. Clin. Invest. 2009, 119, 3626-3636. [CrossRef]

66. Escriva, M.; Peiro, S.; Herranz, N.; Villagrasa, P.; Dave, N.; Montserrat-Sentis, B.; Murray, S.A.; Franci, C.; Gridley, T.; Virtanen, I.; et al. Repression of PTEN phosphatase by Snail1 transcriptional factor during gamma radiation-induced apoptosis. Mol. Cell Biol. 2008, 28, 1528-1540. [CrossRef]

67. Garcia, J.M.; Silva, J.; Pena, C.; Garcia, V.; Rodriguez, R.; Cruz, M.A.; Cantos, B.; Provencio, M.; Espana, P.; Bonilla, F. Promoter methylation of the PTEN gene is a common molecular change in breast cancer. Genes Chrom. Cancer 2004, 41, 117-124. [CrossRef]

68. Goel, A.; Arnold, C.N.; Niedzwiecki, D.; Carethers, J.M.; Dowell, J.M.; Wasserman, L.; Compton, C.; Mayer, R.J.; Bertagnolli, M.M.; Boland, C.R. Frequent inactivation of PTEN by promoter hypermethylation in microsatellite instability-high sporadic colorectal cancers. Cancer Res. 2004, 64, 3014-3021. [CrossRef] 
69. Khan, S.; Kumagai, T.; Vora, J.; Bose, N.; Sehgal, I.; Koeffler, P.H.; Bose, S. PTEN promoter is methylated in a proportion of invasive breast cancers. Int. J. Cancer 2004, 112, 407-410. [CrossRef]

70. Phuong, N.T.; Kim, S.K.; Lim, S.C.; Kim, H.S.; Kim, T.H.; Lee, K.Y.; Ahn, S.G.; Yoon, J.H.; Kang, K.W. Role of PTEN promoter methylation in tamoxifen-resistant breast cancer cells. Breast Cancer Res. Treat. 2011, 130, 73-83. [CrossRef]

71. Soria, J.C.; Lee, H.Y.; Lee, J.I.; Wang, L.; Issa, J.P.; Kemp, B.L.; Liu, D.D.; Kurie, J.M.; Mao, L.; Khuri, F.R. Lack of PTEN expression in non-small cell lung cancer could be related to promoter methylation. Clin. Cancer Res. 2002, 8, 1178-1184.

72. Maeda, M.; Murakami, Y.; Watari, K.; Kuwano, M.; Izumi, H.; Ono, M. CpG hypermethylation contributes to decreased expression of PTEN during acquired resistance to gefitinib in human lung cancer cell lines. Lung Cancer 2015, 87, 265-271. [CrossRef]

73. Ho, C.M.; Lin, M.C.; Huang, S.H.; Huang, C.J.; Lai, H.C.; Chien, T.Y.; Chang, S.F. PTEN promoter methylation and LOH of 10q22-23 locus in PTEN expression of ovarian clear cell adenocarcinomas. Gynecol. Oncol. 2009, 112, 307-313. [CrossRef]

74. Qi, Q.; Ling, Y.; Zhu, M.; Zhou, L.; Wan, M.; Bao, Y.; Liu, Y. Promoter region methylation and loss of protein expression of PTEN and significance in cervical cancer. Biomed. Rep. 2014, 2, 653-658. [CrossRef]

75. Huhns, M.; Salem, T.; Schneider, B.; Krohn, M.; Linnebacher, M.; Prall, F. PTEN mutation, loss of heterozygosity, promoter methylation and expression in colorectal carcinoma: Two hits on the gene? Oncol. Rep. 2014, 31, 2236-2244. [CrossRef]

76. Alvarez-Nunez, F.; Bussaglia, E.; Mauricio, D.; Ybarra, J.; Vilar, M.; Lerma, E.; de Leiva, A.; Matias-Guiu, X.; Thyroid Neoplasia Study Group. PTEN promoter methylation in sporadic thyroid carcinomas. Thyroid 2006, 16,17-23. [CrossRef]

77. Hashemi, M.; Rezaei, H.; Eskandari-Nasab, E.; Kaykhaei, M.A.; Taheri, M. Association of promoter methylation and 32-bp deletion of the PTEN gene with susceptibility to metabolic syndrome. Mol. Med. Rep. 2013, 7, 342-346. [CrossRef]

78. Hino, R.; Uozaki, H.; Murakami, N.; Ushiku, T.; Shinozaki, A.; Ishikawa, S.; Morikawa, T.; Nakaya, T.; Sakatani, T.; Takada, K.; et al. Activation of DNA methyltransferase 1 by EBV latent membrane protein 2A leads to promoter hypermethylation of PTEN gene in gastric carcinoma. Cancer Res. 2009, 69, 2766-2774. [CrossRef]

79. Lu, J.; Jeong, H.W.; Kong, N.; Yang, Y.; Carroll, J.; Luo, H.R.; Silberstein, L.E.; Yupoma; Chai, L. Stem cell factor SALL4 represses the transcriptions of PTEN and SALL1 through an epigenetic repressor complex. PLOS ONE 2009, 4, 5577. [CrossRef]

80. Liu, C.; Wu, H.; Li, Y.; Shen, L.; Yu, R.; Yin, H.; Sun, T.; Sun, C.; Zhou, Y.; Du, Z. SALL4 suppresses PTEN expression to promote glioma cell proliferation via PI3K/AKT signaling pathway. J. Neur. 2017, 135, $263-272$. [CrossRef]

81. Yoshimi, A.; Goyama, S.; Watanabe-Okochi, N.; Yoshiki, Y.; Nannya, Y.; Nitta, E.; Arai, S.; Sato, T.; Shimabe, M.; Nakagawa, M.; et al. Evi1 represses PTEN expression and activates PI3K/AKT/mTOR via interactions with polycomb proteins. Blood 2011, 117, 3617-3628. [CrossRef]

82. Meng, F.; Henson, R.; Wehbe-Janek, H.; Ghoshal, K.; Jacob, S.T.; Patel, T. MicroRNA-21 regulates expression of the PTEN tumor suppressor gene in human hepatocellular cancer. Gastroenterology 2007, 133, 647-658. [CrossRef]

83. Yang, S.M.; Huang, C.; Li, X.F.; Yu, M.Z.; He, Y.; Li, J. miR-21 confers cisplatin resistance in gastric cancer cells by regulating PTEN. Toxicology 2013, 306, 162-168. [CrossRef]

84. Zhang, W.; Bai, W.; Zhang, W. MiR-21 suppresses the anticancer activities of curcumin by targeting PTEN gene in human non-small cell lung cancer A549 cells. Clin. Transl. Oncol. 2014, 16, 708-713. [CrossRef]

85. He, C.; Dong, X.; Zhai, B.; Jiang, X.; Dong, D.; Li, B.; Jiang, H.; Xu, S.; Sun, X. MiR-21 mediates sorafenib resistance of hepatocellular carcinoma cells by inhibiting autophagy via the PTEN/Akt pathway. Oncotarget 2015, 6, 28867-28881. [CrossRef]

86. Song, L.; Liu, S.; Zhang, L.; Yao, H.; Gao, F.; Xu, D.; Li, Q. MiR-21 modulates radiosensitivity of cervical cancer through inhibiting autophagy via the PTEN/Akt/HIF-1alpha feedback loop and the Akt-mTOR signaling pathway. Tumour Biol. 2016, 37, 12161-12168. [CrossRef] 
87. Tumaneng, K.; Schlegelmilch, K.; Russell, R.C.; Yimlamai, D.; Basnet, H.; Mahadevan, N.; Fitamant, J.; Bardeesy, N.; Camargo, F.D.; Guan, K.L. YAP mediates crosstalk between the Hippo and PI(3)K-TOR pathways by suppressing PTEN via miR-29. Nat. Cell Biol. 2012, 14, 1322-1329. [CrossRef]

88. Shen, H.; Li, L.; Yang, S.; Wang, D.; Zhong, S.; Zhao, J.; Tang, J. MicroRNA-29a contributes to drug-resistance of breast cancer cells to adriamycin through PTEN/AKT/GSK3beta signaling pathway. Gene 2016, 593, 84-90. [CrossRef]

89. Zheng, J.; Wu, C.; Lin, Z.; Guo, Y.; Shi, L.; Dong, P.; Lu, Z.; Gao, S.; Liao, Y.; Chen, B.; et al. Curcumin up-regulates phosphatase and tensin homologue deleted on chromosome 10 through microRNA-mediated control of DNA methylation-a novel mechanism suppressing liver fibrosis. FEBS J. 2014, 281, 88-103. [CrossRef]

90. Yang, Y.L.; Wang, F.S.; Li, S.C.; Tiao, M.M.; Huang, Y.H. MicroRNA-29a Alleviates Bile Duct Ligation Exacerbation of Hepatic Fibrosis in Mice through Epigenetic Control of Methyltransferases. Int. J. Mol. Sci. 2017, 18. [CrossRef]

91. Chang, R.M.; Xu, J.F.; Fang, F.; Yang, H.; Yang, L.Y. MicroRNA-130b promotes proliferation and EMT-induced metastasis via PTEN/p-AKT/HIF-1alpha signaling. Tumour Biol. 2016, 37, 10609-10619. [CrossRef] [PubMed]

92. Egawa, H.; Jingushi, K.; Hirono, T.; Ueda, Y.; Kitae, K.; Nakata, W.; Fujita, K.; Uemura, M.; Nonomura, N.; Tsujikawa, K. The miR-130 family promotes cell migration and invasion in bladder cancer through FAK and Akt phosphorylation by regulating PTEN. Sci. Rep. 2016, 6, 20574. [CrossRef] [PubMed]

93. Wei, H.; Cui, R.; Bahr, J.; Zanesi, N.; Luo, Z.; Meng, W.; Liang, G.; Croce, C.M. miR-130a Deregulates PTEN and Stimulates Tumor Growth. Cancer Res. 2017, 77, 6168-6178. [CrossRef] [PubMed]

94. Poliseno, L.; Salmena, L.; Zhang, J.; Carver, B.; Haveman, W.J.; Pandolfi, P.P. A coding-independent function of gene and pseudogene mRNAs regulates tumour biology. Nature 2010, 465, 1033-1038. [CrossRef] [PubMed]

95. Wang, L.; Zhang, N.; Wang, Z.; Ai, D.M.; Cao, Z.Y.; Pan, H.P. Pseudogene PTENP1 Functions as a Competing Endogenous RNA (ceRNA) to Regulate PTEN Expression by Sponging miR-499-5p. Biochemistry 2016, 81, 739-747. [CrossRef]

96. Guo, X.; Deng, L.; Deng, K.; Wang, H.; Shan, T.; Zhou, H.; Liang, Z.; Xia, J.; Li, C. Pseudogene PTENP1 Suppresses Gastric Cancer Progression by Modulating PTEN. Anticancer Agents Med. Chem. 2016, 16, 456-464. [CrossRef]

97. Li, R.K.; Gao, J.; Guo, L.H.; Huang, G.Q.; Luo, W.H. PTENP1 acts as a ceRNA to regulate PTEN by sponging miR-19b and explores the biological role of PTENP1 in breast cancer. Cancer Gene Ther. 2017, 24, 309-315. [CrossRef]

98. Qian, Y.Y.; Li, K.; Liu, Q.Y.; Liu, Z.S. Long non-coding RNA PTENP1 interacts with miR-193a-3p to suppress cell migration and invasion through the PTEN pathway in hepatocellular carcinoma. Oncotarget 2017, 8, 107859-107869. [CrossRef]

99. Chen, S.; Wang, Y.; Zhang, J.H.; Xia, Q.J.; Sun, Q.; Li, Z.K.; Zhang, J.G.; Tang, M.S.; Dong, M.S. Long non-coding RNA PTENP1 inhibits proliferation and migration of breast cancer cells via AKT and MAPK signaling pathways. Oncol. Lett. 2017, 14, 4659-4662. [CrossRef]

100. Zhang, R.; Guo, Y.; Ma, Z.; Ma, G.; Xue, Q.; Li, F.; Liu, L. Long non-coding RNA PTENP1 functions as a ceRNA to modulate PTEN level by decoying miR-106b and miR-93 in gastric cancer. Oncotarget 2017, 8, 26079-26089. [CrossRef]

101. Gao, L.; Ren, W.; Zhang, L.; Li, S.; Kong, X.; Zhang, H.; Dong, J.; Cai, G.; Jin, C.; Zheng, D.; et al. PTENp1, a natural sponge of miR-21, mediates PTEN expression to inhibit the proliferation of oral squamous cell carcinoma. Mol. Carcinog. 2017, 56, 1322-1334. [CrossRef] [PubMed]

102. Guo, C.; Song, W.Q.; Sun, P.; Jin, L.; Dai, H.Y. LncRNA-GAS5 induces PTEN expression through inhibiting miR-103 in endometrial cancer cells. J. Biomed. Sci. 2015, 22, 100. [CrossRef] [PubMed]

103. Xia, T.; Chen, S.; Jiang, Z.; Shao, Y.; Jiang, X.; Li, P.; Xiao, B.; Guo, J. Long noncoding RNA FER1L4 suppresses cancer cell growth by acting as a competing endogenous RNA and regulating PTEN expression. Sci. Rep. 2015, 5, 13445. [CrossRef] [PubMed]

104. Qiao, Q.; Li, H. LncRNA FER1L4 suppresses cancer cell proliferation and cycle by regulating PTEN expression in endometrial carcinoma. Biochem. Biophys. Res. Commun. 2016, 478, 507-512. [CrossRef] [PubMed]

105. Chang, S.; Chen, B.; Wang, X.; Wu, K.; Sun, Y. Long non-coding RNA XIST regulates PTEN expression by sponging miR-181a and promotes hepatocellular carcinoma progression. BMC Cancer 2017, 17, 248. [CrossRef] 
106. Gu, S.; Xie, R.; Liu, X.; Shou, J.; Gu, W.; Che, X. Long Coding RNA XIST Contributes to Neuronal Apoptosis through the Downregulation of AKT Phosphorylation and Is Negatively Regulated by miR-494 in Rat Spinal Cord Injury. Int. J. Mol. Sci. 2017, 18. [CrossRef]

107. Li, Y.; Gu, J.; Lu, H. The GAS5/miR-222 Axis Regulates Proliferation of Gastric Cancer Cells Through the PTEN/Akt/mTOR Pathway. Dig. Dis. Sci. 2017, 62, 3426-3437. [CrossRef] [PubMed]

108. Pan, C.; Yao, G.; Liu, B.; Ma, T.; Xia, Y.; Wei, K.; Wang, J.; Xu, J.; Chen, L.; Chen, Y. Long Noncoding RNA FAL1 Promotes Cell Proliferation, Invasion and Epithelial-Mesenchymal Transition Through the PTEN/AKT Signaling Axis in Non-Small Cell Lung Cancer. Cell Physiol. Biochem. 2017, 43, 339-352. [CrossRef]

109. Qin, N.; Tong, G.F.; Sun, L.W.; Xu, X.L. Long Noncoding RNA MEG3 Suppresses Glioma Cell Proliferation, Migration, and Invasion by Acting as a Competing Endogenous RNA of miR-19a. Oncol. Res. 2017, 25, 1471-1478. [CrossRef]

110. Tao, H.; Zhang, J.G.; Qin, R.H.; Dai, C.; Shi, P.; Yang, J.J.; Deng, Z.Y.; Shi, K.H. LncRNA GAS5 controls cardiac fibroblast activation and fibrosis by targeting miR-21 via PTEN/MMP-2 signaling pathway. Toxicology 2017, 386, 11-18. [CrossRef]

111. Wu, Z.; He, Y.; Li, D.; Fang, X.; Shang, T.; Zhang, H.; Zheng, X. Long noncoding RNA MEG3 suppressed endothelial cell proliferation and migration through regulating miR-21. Am. J. Transl. Res. 2017, 9, 3326-3335. [PubMed]

112. Yang, C.; Wang, G.; Yang, J.; Wang, L. Long noncoding RNA NBAT1 negatively modulates growth and metastasis of osteosarcoma cells through suppression of miR-21. Am. J. Cancer Res. 2017, 7, 2009-2019. [PubMed]

113. Zhu, B.; Gong, Y.; Yan, G.; Wang, D.; Qiao, Y.; Wang, Q.; Liu, B.; Hou, J.; Li, R.; Tang, C. Down-regulation of lncRNA MEG3 promotes hypoxia-induced human pulmonary artery smooth muscle cell proliferation and migration via repressing PTEN by sponging miR-21. Biochem. Biophys Res. Commun. 2018, 495, 2125-2132. [CrossRef] [PubMed]

114. Han, W.; Liu, J. LncRNA-p21 inhibited the proliferation of osteosarcoma cells via the miR-130b/PTEN/AKT signaling pathway. Biomed. Pharm. 2018, 97, 911-918. [CrossRef] [PubMed]

115. Liu, H.; Li, H.; Jin, L.; Li, G.; Hu, S.; Ning, C.; Guo, J.; Shuai, S.; Li, X.; Li, M. Long Noncoding RNA GAS5 Suppresses 3T3-L1 Cells Adipogenesis Through miR-21a-5p/PTEN Signal Pathway. DNA Cell Biol. 2018, 37, 767-777. [CrossRef] [PubMed]

116. Zheng, Q.; Lin, Z.; Xu, J.; Lu, Y.; Meng, Q.; Wang, C.; Yang, Y.; Xin, X.; Li, X.; Pu, H.; et al. Long noncoding RNA MEG3 suppresses liver cancer cells growth through inhibiting beta-catenin by activating PKM2 and inactivating PTEN. Cell Death Dis. 2018, 9, 253. [CrossRef]

117. Li, D.; Feng, J.; Wu, T.; Wang, Y.; Sun, Y.; Ren, J.; Liu, M. Long intergenic noncoding RNA HOTAIR is overexpressed and regulates PTEN methylation in laryngeal squamous cell carcinoma. Am. J. Pathol. 2013, 182, 64-70. [CrossRef]

118. Lai, Y.; He, S.; Ma, L.; Lin, H.; Ren, B.; Ma, J.; Zhu, X.; Zhuang, S. HOTAIR functions as a competing endogenous RNA to regulate PTEN expression by inhibiting miR-19 in cardiac hypertrophy. Mol. Cell Biochem. 2017, 432, 179-187. [CrossRef]

119. Yu, F.; Chen, B.; Dong, P.; Zheng, J. HOTAIR Epigenetically Modulates PTEN Expression via MicroRNA-29b: A Novel Mechanism in Regulation of Liver Fibrosis. Mol. Ther. 2017, 25, 205-217. [CrossRef]

120. Lu, R.; Zhao, G.; Yang, Y.; Jiang, Z.; Cai, J.; Zhang, Z.; Hu, H. Long noncoding RNA HOTAIRM1 inhibits cell progression by regulating miR-17-5p/ PTEN axis in gastric cancer. J. Cell Biochem. 2018, 120, 4952-4965. [CrossRef]

121. Vazquez, F.; Ramaswamy, S.; Nakamura, N.; Sellers, W.R. Phosphorylation of the PTEN tail regulates protein stability and function. Mol. Cell Biol. 2000, 20, 5010-5018. [CrossRef] [PubMed]

122. Torres, J.; Pulido, R. The tumor suppressor PTEN is phosphorylated by the protein kinase CK2 at its C terminus. Implications for PTEN stability to proteasome-mediated degradation. J. Biol. Chem. 2001, 276, 993-998. [CrossRef] [PubMed]

123. Torres, J.; Rodriguez, J.; Myers, M.P.; Valiente, M.; Graves, J.D.; Tonks, N.K.; Pulido, R. Phosphorylation-regulated cleavage of the tumor suppressor PTEN by caspase-3: Implications for the control of protein stability and PTEN-protein interactions. J. Biol. Chem. 2003, 278, 30652-30660. [CrossRef] [PubMed] 
124. Maccario, H.; Perera, N.M.; Davidson, L.; Downes, C.P.; Leslie, N.R. PTEN is destabilized by phosphorylation on Thr366. Biochem. J. 2007, 405, 439-444. [CrossRef] [PubMed]

125. Tolkacheva, T.; Boddapati, M.; Sanfiz, A.; Tsuchida, K.; Kimmelman, A.C.; Chan, A.M. Regulation of PTEN binding to MAGI-2 by two putative phosphorylation sites at threonine 382 and 383. Cancer Res. 2001, 61, 4985-4989. [PubMed]

126. Yang, Z.; Xie, C.; Xu, W.; Liu, G.; Cao, X.; Li, W.; Chen, J.; Zhu, Y.; Luo, S.; Luo, Z.; et al. Phosphorylation and inactivation of PTEN at residues Ser380/Thr382/383 induced by Helicobacter pylori promotes gastric epithelial cell survival through PI3K/Akt pathway. Oncotarget 2015, 6, 31916-31926. [CrossRef] [PubMed]

127. Pua, T.L.; Wang, F.Q.; Fishman, D.A. Roles of LPA in ovarian cancer development and progression. Future Oncol. 2009, 5, 1659-1673. [CrossRef]

128. Rahdar, M.; Inoue, T.; Meyer, T.; Zhang, J.; Vazquez, F.; Devreotes, P.N. A phosphorylation-dependent intramolecular interaction regulates the membrane association and activity of the tumor suppressor PTEN. Proc. Natl. Acad. Sci. USA 2009, 106, 480-485. [CrossRef]

129. Trotman, L.C.; Wang, X.; Alimonti, A.; Chen, Z.; Teruya-Feldstein, J.; Yang, H.; Pavletich, N.P.; Carver, B.S.; Cordon-Cardo, C.; Erdjument-Bromage, H.; et al. Ubiquitination regulates PTEN nuclear import and tumor suppression. Cell 2007, 128, 141-156. [CrossRef]

130. Yan, Y.; Li, Z.; Zeng, S.; Wang, X.; Gong, Z.; Xu, Z. FGFR2-mediated phosphorylation of PTEN at tyrosine 240 contributes to the radioresistance of glioma. J. Cell Commun. Signal. 2019, 13, 279-280. [CrossRef]

131. Fenton, T.R.; Nathanson, D.; Ponte de Albuquerque, C.; Kuga, D.; Iwanami, A.; Dang, J.; Yang, H.; Tanaka, K.; Oba-Shinjo, S.M.; Uno, M.; et al. Resistance to EGF receptor inhibitors in glioblastoma mediated by phosphorylation of the PTEN tumor suppressor at tyrosine 240. Proc. Natl. Acad. Sci. USA 2012, 109, 14164-14169. [CrossRef]

132. Wang, X.; Trotman, L.C.; Koppie, T.; Alimonti, A.; Chen, Z.; Gao, Z.; Wang, J.; Erdjument-Bromage, H.; Tempst, P.; Cordon-Cardo, C.; et al. NEDD4-1 is a proto-oncogenic ubiquitin ligase for PTEN. Cell 2007, 128, 129-139. [CrossRef]

133. Wang, X.; Shi, Y.; Wang, J.; Huang, G.; Jiang, X. Crucial role of the C-terminus of PTEN in antagonizing NEDD4-1-mediated PTEN ubiquitination and degradation. Biochem. J. 2008, 414, 221-229. [CrossRef]

134. Ahmed, S.F.; Deb, S.; Paul, I.; Chatterjee, A.; Mandal, T.; Chatterjee, U.; Ghosh, M.K. The chaperone-assisted E3 ligase $\mathrm{C}$ terminus of Hsc70-interacting protein (CHIP) targets PTEN for proteasomal degradation. J. Biol. Chem. 2012, 287, 15996-16006. [CrossRef]

135. Li, N.; Zhang, Y.; Han, X.; Liang, K.; Wang, J.; Feng, L.; Wang, W.; Songyang, Z.; Lin, C.; Yang, L.; et al. Poly-ADP ribosylation of PTEN by tankyrases promotes PTEN degradation and tumor growth. Genes Dev. 2015, 29, 157-170. [CrossRef]

136. Maddika, S.; Kavela, S.; Rani, N.; Palicharla, V.R.; Pokorny, J.L.; Sarkaria, J.N.; Chen, J. WWP2 is an E3 ubiquitin ligase for PTEN. Nat. Cell Biol. 2011, 13, 728-733. [CrossRef]

137. Li, H.; Zhang, P.; Zhang, Q.; Li, C.; Zou, W.; Chang, Z.; Cui, C.P.; Zhang, L. WWP2 is a physiological ubiquitin ligase for phosphatase and tensin homolog (PTEN) in mice. J. Biol. Chem. 2018, 293, 8886-8899. [CrossRef]

138. Zhang, L.; Wu, Z.; Ma, Z.; Liu, H.; Wu, Y.; Zhang, Q. WWP1 as a potential tumor oncogene regulates PTEN-Akt signaling pathway in human gastric carcinoma. Tumour Biol. 2015, 36, 787-798. [CrossRef]

139. Lee, Y.R.; Chen, M.; Lee, J.D.; Zhang, J.; Lin, S.Y.; Fu, T.M.; Chen, H.; Ishikawa, T.; Chiang, S.Y.; Katon, J.; et al. Reactivation of PTEN tumor suppressor for cancer treatment through inhibition of a MYC-WWP1 inhibitory pathway. Science 2019, 364, 159. [CrossRef]

140. Van Themsche, C.; Leblanc, V.; Parent, S.; Asselin, E. X-linked inhibitor of apoptosis protein (XIAP) regulates PTEN ubiquitination, content, and compartmentalization. J. Biol. Chem. 2009, 284, 20462-20466. [CrossRef]

141. Lee, S.R.; Yang, K.S.; Kwon, J.; Lee, C.; Jeong, W.; Rhee, S.G. Reversible inactivation of the tumor suppressor PTEN by H2O2. J. Biol. Chem. 2002, 277, 20336-20342. [CrossRef]

142. Kwon, J.; Lee, S.R.; Yang, K.S.; Ahn, Y.; Kim, Y.J.; Stadtman, E.R.; Rhee, S.G. Reversible oxidation and inactivation of the tumor suppressor PTEN in cells stimulated with peptide growth factors. Proc. Natl. Acad. Sci. USA 2004, 101, 16419-16424. [CrossRef]

143. Okumura, K.; Mendoza, M.; Bachoo, R.M.; DePinho, R.A.; Cavenee, W.K.; Furnari, F.B. PCAF modulates PTEN activity. J. Biol. Chem. 2006, 281, 26562-26568. [CrossRef]

144. Ikenoue, T.; Inoki, K.; Zhao, B.; Guan, K.L. PTEN acetylation modulates its interaction with PDZ domain. Cancer Res. 2008, 68, 6908-6912. [CrossRef] 
145. Meng, Z.; Jia, L.F.; Gan, Y.H. PTEN activation through K163 acetylation by inhibiting HDAC6 contributes to tumour inhibition. Oncogene 2016, 35, 2333-2344. [CrossRef]

146. Numajiri, N.; Takasawa, K.; Nishiya, T.; Tanaka, H.; Ohno, K.; Hayakawa, W.; Asada, M.; Matsuda, H.; Azumi, K.; Kamata, H.; et al. On-off system for PI3-kinase-Akt signaling through S-nitrosylation of phosphatase with sequence homology to tensin (PTEN). Proc. Natl. Acad. Sci. USA 2011, 108, 10349-10354. [CrossRef]

147. Huang, J.; Yan, J.; Zhang, J.; Zhu, S.; Wang, Y.; Shi, T.; Zhu, C.; Chen, C.; Liu, X.; Cheng, J.; et al. SUMO1 modification of PTEN regulates tumorigenesis by controlling its association with the plasma membrane. Nat. Commun. 2012, 3, 911. [CrossRef]

148. Fouladkou, F.; Landry, T.; Kawabe, H.; Neeb, A.; Lu, C.; Brose, N.; Stambolic, V.; Rotin, D. The ubiquitin ligase Nedd4- 1 is dispensable for the regulation of PTEN stability and localization. Proc. Natl. Acad. Sci. USA 2008, 105, 8585-8590. [CrossRef]

149. Covey, T.M.; Edes, K.; Fitzpatrick, F.A. Akt activation by arachidonic acid metabolism occurs via oxidation and inactivation of PTEN tumor suppressor. Oncogene 2007, 26, 5784-5792. [CrossRef]

150. Hui, S.T.; Andres, A.M.; Miller, A.K.; Spann, N.J.; Potter, D.W.; Post, N.M.; Chen, A.Z.; Sachithanantham, S.; Jung, D.Y.; Kim, J.K.; et al. Txnip balances metabolic and growth signaling via PTEN disulfide reduction. Proc. Natl. Acad. Sci. USA 2008, 105, 3921-3926. [CrossRef]

151. Shen, S.M.; Guo, M.; Xiong, Z.; Yu, Y.; Zhao, X.Y.; Zhang, F.F.; Chen, G.Q. AIF inhibits tumor metastasis by protecting PTEN from oxidation. EMBO Rep. 2015, 16, 1563-1580. [CrossRef] [PubMed]

152. Pei, D.S.; Sun, Y.F.; Song, Y.J. S-nitrosylation of PTEN Invovled in ischemic brain injury in rat hippocampal CA1 region. Neurochem Res. 2009, 34, 1507-1512. [CrossRef] [PubMed]

153. Gupta, A.; Anjomani-Virmouni, S.; Koundouros, N.; Dimitriadi, M.; Choo-Wing, R.; Valle, A.; Zheng, Y.; Chiu, Y.H.; Agnihotri, S.; Zadeh, G.; et al. PARK2 Depletion Connects Energy and Oxidative Stress to PI3K/Akt Activation via PTEN S-Nitrosylation. Mol. Cell 2017, 65, 999-1013. [CrossRef] [PubMed]

154. Gupta, A.; Anjomani-Virmouni, S.; Koundouros, N.; Poulogiannis, G. PARK2 loss promotes cancer progression via redox-mediated inactivation of PTEN. Mol. Cell Oncol. 2017, 4, 1329692. [CrossRef]

155. Zhu, L.; Li, L.; Zhang, Q.; Yang, X.; Zou, Z.; Hao, B.; Marincola, F.M.; Liu, Z.; Zhong, Z.; Wang, M.; et al. NOS1 S-nitrosylates PTEN and inhibits autophagy in nasopharyngeal carcinoma cells. Cell Death Discov. 2017, 3, 17011. [CrossRef]

156. Zhao, J.J.; Cheng, H.; Jia, S.; Wang, L.; Gjoerup, O.V.; Mikami, A.; Roberts, T.M. The p110 $\alpha$ isoform of PI3K is essential for proper growth factor signaling and oncogenic transformation. Proc. Natl. Acad. Sci. USA 2006, 103, 16296-16300. [CrossRef]

157. Gupta, S.; Ramjaun, A.R.; Haiko, P.; Wang, Y.; Warne, P.H.; Nicke, B.; Nye, E.; Stamp, G.; Alitalo, K.; Downward, J. Binding of ras to phosphoinositide 3-kinase p110alpha is required for ras-driven tumorigenesis in mice. Cell 2007, 129, 957-968. [CrossRef]

158. Jiang, X.; Chen, S.; Asara, J.M.; Balk, S.P. Phosphoinositide 3-kinase pathway activation in phosphate and tensin homolog (PTEN)-deficient prostate cancer cells is independent of receptor tyrosine kinases and mediated by the p110beta and p110delta catalytic subunits. J. Biol. Chem. 2010, 285, 14980-14989. [CrossRef]

159. Cizmecioglu, O.; Ni, J.; Xie, S.; Zhao, J.J.; Roberts, T.M. Rac1-mediated membrane raft localization of $\mathrm{PI} 3 \mathrm{~K} / \mathrm{p} 110 \mathrm{beta}$ is required for its activation by GPCRs or PTEN loss. eLife 2016, 5, 17635. [CrossRef]

160. Lasserre, R.; Guo, X.J.; Conchonaud, F.; Hamon, Y.; Hawchar, O.; Bernard, A.M.; Soudja, S.M.; Lenne, P.F.; Rigneault, H.; Olive, D.; et al. Raft nanodomains contribute to Akt/PKB plasma membrane recruitment and activation. Nat. Chem. Biol. 2008, 4, 538-547. [CrossRef]

161. Fritsch, R.; de Krijger, I.; Fritsch, K.; George, R.; Reason, B.; Kumar, M.S.; Diefenbacher, M.; Stamp, G.; Downward, J. RAS and RHO families of GTPases directly regulate distinct phosphoinositide 3-kinase isoforms. Cell 2013, 153, 1050-1063. [CrossRef]

162. Welch, H.C.; Coadwell, W.J.; Stephens, L.R.; Hawkins, P.T. Phosphoinositide 3-kinase-dependent activation of Rac. FEBS Lett. 2003, 546, 93-97. [CrossRef]

163. Yuzugullu, H.; Baitsch, L.; Von, T.; Steiner, A.; Tong, H.; Ni, J.; Clayton, L.K.; Bronson, R.; Roberts, T.M.; Gritsman, K.; et al. A PI3K p110beta-Rac signalling loop mediates Pten-loss-induced perturbation of haematopoiesis and leukaemogenesis. Nat. Commun. 2015, 6, 8501. [CrossRef]

164. Zhang, J.; Gao, X.; Schmit, F.; Adelmant, G.; Eck, M.J.; Marto, J.A.; Zhao, J.J.; Roberts, T.M. CRKL Mediates p110beta-Dependent PI3K Signaling in PTEN-Deficient Cancer Cells. Cell Rep. 2017, 20, 549-557. [CrossRef] 
165. Sharma, A.; Mayer, B.J. Phosphorylation of p130Cas initiates Rac activation and membrane ruffling. BMC Cell Biol. 2008, 9, 50. [CrossRef]

166. Wozniak, M.A.; Modzelewska, K.; Kwong, L.; Keely, P.J. Focal adhesion regulation of cell behavior. Biochim. Bio. Acta. 2004, 1692, 103-119. [CrossRef]

167. Lin, Z.; Zhou, P.; von Gise, A.; Gu, F.; Ma, Q.; Chen, J.; Guo, H.; van Gorp, P.R.; Wang, D.Z.; Pu, W.T. Pi3kcb links Hippo-YAP and PI3K-AKT signaling pathways to promote cardiomyocyte proliferation and survival. Circ. Res. 2015, 116, 35-45. [CrossRef]

168. Jang, J.W.; Kim, M.K.; Lee, Y.S.; Lee, J.W.; Kim, D.M.; Song, S.H.; Lee, J.Y.; Choi, B.Y.; Min, B.; Chi, X.Z.; et al. RAC-LATS1/2 signaling regulates YAP activity by switching between the YAP-binding partners TEAD4 and RUNX3. Oncogene 2017, 36, 999-1011. [CrossRef]

169. Sethi, I.; Cai, Z.; Roberts, T.M.; Yuan, G.C. Molecular Profiling Establishes Genetic Features Predictive of the Efficacy of the p110beta Inhibitor KIN-193. Cancer Res. 2019, 79, 4524-4531. [CrossRef]

170. Rodon, J.; Dienstmann, R.; Serra, V.; Tabernero, J. Development of PI3K inhibitors: Lessons learned from early clinical trials. Nat. Rev. Clin. Oncol. 2013, 10, 143-153. [CrossRef]

171. Yap, T.A.; Bjerke, L.; Clarke, P.A.; Workman, P. Drugging PI3K in cancer: Refining targets and therapeutic strategies. Curr. Opin. Pharm. 2015, 23, 98-107. [CrossRef] [PubMed]

172. Mateo, J.; Ganji, G.; Lemech, C.; Burris, H.A.; Han, S.W.; Swales, K.; Decordova, S.; DeYoung, M.P.; Smith, D.A.; Kalyana-Sundaram, S.; et al. A First-Time-in-Human Study of GSK2636771, a Phosphoinositide 3 Kinase Beta-Selective Inhibitor, in Patients with Advanced Solid Tumors. Clin. Cancer Res. 2017, 23, 5981-5992. [CrossRef] [PubMed]

173. Hansen, A.R.; Shapiro, G.; Do, K.T.; Kumar, R.; Martin-Liberal, J.; Higano, C.S.; Wisinski, K.B.; Dean, E.J.; Heath, E.I.; Rathkopf, D.E.; et al. A first in human phase I study of AZD8186, a potent and selective inhibitor of PI3K in patients with advanced solid tumours as monotherapy and in combination with the dual mTORC1/2 inhibitor vistusertib (AZD2014) or abiraterone acetate. J. Clin. Oncol. 2017, 35, 2570. [CrossRef]

174. Saura, C.; Roda, D.; Rosello, S.; Oliveira, M.; Macarulla, T.; Perez-Fidalgo, J.A.; Morales-Barrera, R.; Sanchis-Garcia, J.M.; Musib, L.; Budha, N.; et al. A First-in-Human Phase I Study of the ATP-Competitive AKT Inhibitor Ipatasertib Demonstrates Robust and Safe Targeting of AKT in Patients with Solid Tumors. Cancer Discov. 2017, 7, 102-113. [CrossRef] [PubMed]

175. Foukas, L.C.; Claret, M.; Pearce, W.; Okkenhaug, K.; Meek, S.; Peskett, E.; Sancho, S.; Smith, A.J.; Withers, D.J.; Vanhaesebroeck, B. Critical role for the p110alpha phosphoinositide-3-OH kinase in growth and metabolic regulation. Nature 2006, 441, 366-370. [CrossRef]

176. Mulholland, D.J.; Tran, L.M.; Li, Y.; Cai, H.; Morim, A.; Wang, S.; Plaisier, S.; Garraway, I.P.; Huang, J.; Graeber, T.G.; et al. Cell autonomous role of PTEN in regulating castration-resistant prostate cancer growth. Cancer Cell 2011, 19, 792-804. [CrossRef]

177. Rescigno, P.; de Bono, J.; Aparicio, A.; Chowdhury, S.; Twardowski, P.; Dawson, N.; Vaishampayan, U.; Pantuck, A.J.; Zhou, Y.; Fecteau, D.; et al. 792PDPhase I, open-label, dose-finding study of GSK2636771, a phosphoinositide 3-kinase (PI3K) $\beta$ inhibitor, in combination with enzalutamide in male subjects with metastatic castration-resistant prostate cancer (mCRPC). Annals Oncol. 2017, 28, 5. [CrossRef]

178. Suzuki, A.; Yamaguchi, M.T.; Ohteki, T.; Sasaki, T.; Kaisho, T.; Kimura, Y.; Yoshida, R.; Wakeham, A.; Higuchi, T.; Fukumoto, M.; et al. T cell-specific loss of Pten leads to defects in central and peripheral tolerance. Immunity 2001, 14, 523-534. [CrossRef]

179. Peng, W.; Chen, J.Q.; Liu, C.; Malu, S.; Creasy, C.; Tetzlaff, M.T.; Xu, C.; McKenzie, J.A.; Zhang, C.; Liang, X.; et al. Loss of PTEN Promotes Resistance to T Cell-Mediated Immunotherapy. Cancer Discov. 2016, 6, 202-216. [CrossRef]

180. Peng, W.; Xu, C.; Melendez, B.; Jackson, H.; McKenzi, J.A.; Williams, L.J.; Chen, Y.; Mbofung, R.M.; Leahey, S.E.L.E.; Lizee, G.; et al. Abstract 4938: OX40 agonist antibody-based combination therapy with PI3K $\beta$ selective inhibitor enhances T cell immunity. Cancer Res. 2018, 78, 4938. [CrossRef]

181. Tawbi, H.A.-H.; Peng, W.; Milton, D.; Amaria, R.N.; Glitza, I.C.; Hwu, W.-J.; Patel, S.P.; Wong, M.K.K.; Woodman, S.E.; Yee, C.; et al. Phase I/II study of the PI3K $\beta$ inhibitor GSK2636771 in combination with pembrolizumab (P) in patients (pts) with PD-1 refractory metastatic melanoma (MM) and PTEN loss. J. Clin. Oncol. 2018, 36, 9596. [CrossRef]

182. Kaelin, W.G., Jr. The concept of synthetic lethality in the context of anticancer therapy. Nat. Rev. Cancer 2005, 5, 689-698. [CrossRef] [PubMed] 
183. Mendes-Pereira, A.M.; Martin, S.A.; Brough, R.; McCarthy, A.; Taylor, J.R.; Kim, J.S.; Waldman, T.; Lord, C.J.; Ashworth, A. Synthetic lethal targeting of PTEN mutant cells with PARP inhibitors. EMBO Mol. Med. 2009, 1, 315-322. [CrossRef] [PubMed]

184. Zhao, D.; Lu, X.; Wang, G.; Lan, Z.; Liao, W.; Li, J.; Liang, X.; Chen, J.R.; Shah, S.; Shang, X.; et al. Synthetic essentiality of chromatin remodelling factor CHD1 in PTEN-deficient cancer. Nature 2017, 542, 484-488. [CrossRef]

185. Turchick, A.; Liu, Y.; Zhao, W.; Cohen, I.; Glazer, P.M. Synthetic lethality of a cell-penetrating anti-RAD51 antibody in PTEN-deficient melanoma and glioma cells. Oncotarget 2019, 10, 1272-1283. [CrossRef]

186. Ren, W.; Joshi, R.; Mathew, P. Synthetic Lethality in PTEN-Mutant Prostate Cancer Is Induced by Combinatorial PI3K/Akt and BCL-XL Inhibition. Mol. Cancer Res. 2016, 14, 1176-1181. [CrossRef]

187. Li, K.; Yan, H.; Guo, W.; Tang, M.; Zhao, X.; Tong, A.; Peng, Y.; Li, Q.; Yuan, Z. ATM inhibition induces synthetic lethality and enhances sensitivity of PTEN-deficient breast cancer cells to cisplatin. Exp. Cell Res. 2018, 366, 24-33. [CrossRef]

188. Ding, Y.; Li, N.; Dong, B.; Guo, W.; Wei, H.; Chen, Q.; Yuan, H.; Han, Y.; Chang, H.; Kan, S.; et al. Chromatin remodeling ATPase BRG1 and PTEN are synthetic lethal in prostate cancer. J. Clin. Invest. 2019, 129, 759-773. [CrossRef]

189. Chen, P.; Zhao, D.; Li, J.; Liang, X.; Li, J.; Chang, A.; Henry, V.K.; Lan, Z.; Spring, D.J.; Rao, G.; et al. Symbiotic Macrophage-Glioma Cell Interactions Reveal Synthetic Lethality in PTEN-Null Glioma. Cancer Cell 2019, 35, 868-884. [CrossRef]

190. Chatterjee, N.; Pazarentzos, E.; Mayekar, M.K.; Gui, P.; Allegakoen, D.V.; Hrustanovic, G.; Olivas, V.; Lin, L.; Verschueren, E.; Johnson, J.R.; et al. Synthetic Essentiality of Metabolic Regulator PDHK1 in PTEN-Deficient Cells and Cancers. Cell Rep. 2019, 28, 2317-2330. [CrossRef]

191. Schwertassek, U.; Haque, A.; Krishnan, N.; Greiner, R.; Weingarten, L.; Dick, T.P.; Tonks, N.K. Reactivation of oxidized PTP1B and PTEN by thioredoxin 1. FEBS J. 2014, 281, 3545-3558. [CrossRef] [PubMed]

(C) 2019 by the authors. Licensee MDPI, Basel, Switzerland. This article is an open access article distributed under the terms and conditions of the Creative Commons Attribution (CC BY) license (http://creativecommons.org/licenses/by/4.0/). 